\title{
E-Governance in India to Combat COVID-19
}

\author{
Dr. Mangesh M. Ghonge, Mr. Deepak Pathratkar
}

\begin{abstract}
Viral pandemics are a serious threat. COVID-19 is not the first, and it won't be the last. As the whole world is going through the black phase of COVID-19 virus, the scientists are trying to invent a fighting vaccine against the same. Each and every sector in every part of the world is infected by the outburst of the fatal virus. Right from business and trade to sports and entertainment, every aspect of life is suffering a lot. To combat the outbreak of the pandemic, most of the countries have used partial to complete lockdown as the only weapon to stop the spread of the virus. In the current scenario, almost all the private sector companies as well as the government offices have suggested all the employees to work from home to stop the community spread of the disease that may occur if people come in mutual contact. While we think of governing authorities around the world, each and every government provides some e-facilities to their citizens to some what extent. Generally E-Governance can be stated as the facility to receive each and everything electronically i.e. you don't need to go to outside home to receive any document or order. In this paper, we briefly described the different aspects of e-governance.
\end{abstract}

Index Terms - e-governance, COVID-19, digitalized, resources, sectors

\section{INTRODUCTION}

The 2020 pandemic came from the blue like a bolt, and knocked down the complacency of our world for a loop. These disruptions are unusual because they require a mixture of effects, speed and size. They force us to reflect on our position and speed as an intelligent species and make us introspect on some of the flawed designs that our society is casually reclining upon. Such tough times definitely require our focus to contain the threat, but it also often offers an incentive for long-term sectoral reforms to be implemented. In the wake of this crisis, the present treatise focuses on the e-governance opportunities in India.

Rather than formally defining e-governance, it can be said to be the use of electronic means to facilitate the government's fulfilment of its obligation to ensure the smooth delivery of goods and services by public and private players in every sector of the economy. Every time the government uses an e-governance system, it results in more productivity, lower

Manuscript revised on December 19, 2020 and published on January 10, 2021

Dr. Mangesh M. Ghonge, Sandip Institute of Technology and Research Center, Nashik, Maharashtra, India..

Mr. Deepak Pathratkar, Z. P. School, Tq. Ner, Yavatmal, Maharashtra, India prices, lower demands for manpower and less physical involvement of humans in the work at hand [1]. In the lockout and social distancing activities of the current pandemic scenario, the last benefit, and perhaps the penultimate one, is of concern. Also worth mentioning is that if hardware automation and artificial intelligence are added to e-governance, it can reduce the need for manpower and their physical presence in every possible job / economic activity. So, it often comes to the mind that if this pandemic had occurred a century later, then the planet would have been much better able to withstand the shock. Yet sadly no one can predict a whammy 's timing — one can only anticipate its effect and plan ahead of time.

\section{A. What is E-Governance?}

1. The delivery of government services and goods online through the internet or other digital forms.

2. Utilizing the Information and Communication Technology (ICT) for developing and improving mutual beneficial interaction between government citizens, companies and NGO's and other entities.

The advantages of E-Governance

1. Saves labour / Cost

2. Saves time

3. Increases efficiency

As we all know, it can save your efforts and time and at the same time the job is done with more accuracy and efficiency. In short, the government can provide easier and smoother access to goods and services in every sector of life and economy. Automated hardware and AI use will result into minimum manual presence and it will lead to less possibilities of manual contact which will be helpful in maintaining social distance.

\section{B. The objective of E-governance}

The objectives of e-governance can be stated as follows:

- Fostering and simplifying governance for government, people and industry.

- Making governance more open and accountable while addressing the needs and desires of society through efficient public services and effective engagement between citizens, businesses and government

- Reducing Government corruption.

- To ensure speedy administration of services and information

- Providing immediate information and allowing digital communication through e-business to reduce business difficulties. 
While e-governance provides the advantages of convenience, efficiency and transparency, it also has problems associated with it. They are as follows:

- Computer literacy shortages: India remains a developing country, and a vast majority of people lack computer literacy that hinders the effectiveness of e-government.

- Lack of internet connectivity, or even computers in some parts of the world, is an e-governance disadvantage.

- The consequence of e-governance is lack of human contact. Less interaction takes place among people as the system becomes more mechanized.

- This carries the risk of hacking and leakage of personal data.

- E-governance causes a lax government. For technical reasons such as "server is down" or "internet is not running," etc., the service provider may easily explain not delivering the service.

\section{OVERVIEW OF E-GOVERNANCE}

For acquiring the above benefits, E-governance should be more digitized taking into consideration the following domains of governance

1. The resources in India

2. Assigning resources to different sectors of economy as per requirements and merit

3. Coordination between sectors to be more efficient

4. Monitoring of progress

5. Providing sustainable incentives to speed up progress

6. Shuffling resources among sectors as per needs

7. Managing the resources

Digitization in each field of the above can help India successfully pass through vulnerabilities, the country is facing in the outburst of the current pandemic [2].

\section{A. The resources in India}

This domain deals with the available resources i.e. manpower, money, natural resources and infrastructure are those resources.

1. Manpower: The first resource is manpower means human resources we have. Census is the most important thing of them which can subsume all the other surveys. For the expected results, we have to digitize the census in such a way that Aadhar and all the other personal information will be available digitally and thus it will be updated in real time which will save time, money and efforts in providing services to the citizens.

2. Money: The second resources is money; RBI is keeping all the record of money / use of money across the country with minute details. When it comes to digitization UPI is a best and safest way to money transfer and trade. But for the use of crypto currencies in the fourth coming further, RBI will need a broader and wider scanner to supervise the money exchange.

3. Natural resources: This includes
a. land
b. Reserve and distribution of fresh water
c. Vegetation

\section{d. Minerals \\ e. Radio Spectrums \\ f. Air space}

This should be measures in real time based on IoT technologies and those should be displayed on a public interface / dashboard which should be accessible to every individual.

4. Infrastructure: This term includes road, rail, electricity etc. These are allocated to different sectors. These must be recorded and mapped digitally to achieve accuracy and accessibility to each and every citizen.

\section{B. Assigning resources to different sectors of economy as per requirements and merit}

Now second domain is assigning the resources to different sectors of economy. Suppose, if the economy has been digitized $100 \%$ in future, an economy census of the country should be conducted and the relevant database should be merged into the MCA21 database of ministry of Corporate affairs in order to make it equal to census super card, while census data is completely private, these data can be publicly available [3].

This could be of vital use for government to decide on the changes on allocation of resources in different sectors of economy. Both investment and disinvestment can be decided on the basis of same database.

Moreover, with the use of the artificial Intelligence, government can prefer the multi-utility products over the products which have only one purpose.

This may not be so easy but as per the call of the hour, legal amendments should be done for the companies help the government in the hour of emergency.

\section{Coordination between sectors to be more efficient}

The third domain is about coordination of sectors, there are some goods and services which ae constantly being provided by the government to the citizens for their well-being and as a result of that the consumers / citizens are paying taxes to the government which are the real backbone of the Indian economy [4].

These two factors are of opposite directions but they are mutually interdependent, for that there should be a proper coordination between these sectors like household, agriculture and government. The government can act as a middleman between these sectors which sometimes acts as a catalyst. It is in the process but it only contracts the process and does not adversely affect the process.

For example, BHIM (BHarat Interface for Money) is an initiative by government which provides you the banking services on behalf of government. Most of the private companies are offering you home delivery services for each and everything using BHIM UPI services.

INDIA ENTERPRISE ARCHITECTURE is implemented by national e-Governance División of government to streamline the complete government work module which is based on a one government backbone. 


\section{Monitoring System to track the progress of the sectors against planned Dynamic targets}

When we conduct some survey or programme we need to implement these palaces effectively for the best output and in the same way, e-Governance should be implemented for the sake of well-being of human being, while implementing it, we should also monitor the progress of the sectors whether they are going a right way? What is the rate of exposition of progress? What changes of these processes need? What are the new trends in the related sector? And how can it be used to modify the governance sector to ease every factor / aspect of the system?

To monitor all these things, there should be database made up of queries and feedbacks to the given services which would make the government think about what is going well and what is not [5].

For these purposes, google forms like application would play a vital role which would give us a broad idea of the outputs from the e-Governance.

\section{E. Providing Sustainable incentives to expedite}

We all know the human tendency, of working more efficiently when given rewards / incentives. In the same way, every sector should be inspired to work the electronic way i.e. have some e-solutions to every demand of the public or consumers.

If a certain sector is providing all the e-services regarding the sector to their relevant consumers, it should be awarded for that sake in a specific way of other. They should be given some discounts in the taxation or any other expenditure as they are rendering services electronically which ultimately ends in the lesser labour cost and more perfection / efficiently in lesser time.

Some of the others are

- Development of portal websites

- Promotion of IT industries

- Development of IT parks

- Coordination with IT companies for cheaper IT services

- Subsidies on e-services

\section{F. Shuffling resources among sectors as per needs}

To expedite the process of e-governance we should not only study the available resources but as the same time, government must utilize them in as smarter way to achieve the objectives of efficient work in minimum efforts [6].

For example, if the IT department for private companies are having nice experience in establishing an e-platform for certain services, then instead of establishing its own IT-cell government should hire the experts from these companies to solve the issues or to develop the related software.

For example, to offer the e-certificate services or e-salary services the government should tie-up with IT ventures or a new start-up to complete their needs.

This will result in

- Time saving

- Cost cutting

- Smart use of infrastructure

- Training of manual resources
In the same way money and natural resources can be used in a shuffling manner to minimize cost and labour and time.

\section{G. To discover new resources and try to manage them}

Apart from these resources (manpower, money, natural resources, infrastructure) government should focus on using more unconventional resources like AI and solar energy in e-governance which would provide perfect services at a faster rate with more accuracy and efficiency.

\section{POSSIBILITIES OF E-GOVERnANCE}

As a government takes care of every filed of the life of people of India, we would consider it in various fields [7]-[8]-[9]

\section{A. Transport}

The public transport in India is a major issue of concern due to vast population and limited land. The people are using their own uses. But to avoid the crowd and mis-management of schedule public transport, an automatically monitored system can be developed for SRTC buses and private travel agencies which would provide exact idea of the schedule.

A related android app will also add to it, it will safer, smarter and easy to use.

\section{B. Health}

For as stronger country, we need strong and healthy citizens. To track the health of each and every citizen, government should develop smart and easy-to-carry machines to test the health problems. If a citizen registers some health problem on the dedicated health app connected to local health Centre, He should be given possible advice and at the same time an appointment with the available doctor in real time. Such things would be really help. An online health help line would also benefit the needy people.

\section{Education}

E-governance in education deals with educating students on online/offline classes, some digital media, educational apps and interfaces. It also deals with monitoring education system electronically i.e. biometric attendance of students / teachers and all the officials. Government has also developed SARAL database for schools from $1^{\text {st }}$ to $12^{\text {th }}$ class where the admission progress and records of students can be viewed from around the globe. This creates transparency in government policies.

\section{Taxation}

Nowadays all the taxes are cancelled and there is one-India-one Tax i.e. GST. Government has already started GST and Income tax receipt on an online platform with dedicated websites. This will ease the process and save the time and labour and cost to provide easy access to a number of people. 


\section{E. E-readiness}

Is also an important term to be disclosed as for the purpose, government should be electronically ready to ICT to develop economy?

1. Presence: Developing an information providing database/website which is accessible to each and every part of citizens.

2. Stage 2 interaction: G2C, G2B, G2C

3. Transaction: An online transaction portal is to be developed with higher most priority to the economic safety of the government and citizens. Taxes, fees or bids/tender submission should be easier for that.

4. Transformation: This process involves an automatic evaluation and reinvention of how's government funding are conceived and organized.

\section{SECURITY IN E-GOVERNANCE}

Protecting essential information infrastructure, or CIIs, the interconnected information systems and networks, whose disruption or failure would have a significant impact on citizens health, safety, protection, economic well-being and, potentially, the successful functioning of government or economy, is crucial. A well-established and protected CII framework which interacts well with government is also important for the security of a country. Therefore, it is important to consider CII's when developing e-governance systems and how these can impact online services.

Given the need to defend information infrastructures against danger or threat, government officials need to be made awar e of the possible devastating consequences of their destructi on in order to increase mitigation effectiveness [10].

The Global Cybersecurity Index in table 4.1 developed by the International Telecommunication Union can serve as reference for government officials in the process of designing secure e-government systems. Through use of the Index, governments can assess progress in the effective deployment of ICTs and development of cybersecurity strategies. It provides governments with an evaluation of the extent of their wellbeing for cybersecurity and provides strategies for addressing e-government risk. More precisely, the Index measures the kind, degree and evolution of countries' commitment to cybersecurity, 12 which will eventually provide experts with an opportunity to evaluate the performance of those commitments from both regional and global perspectives [10].

India ranks 23rd among 165 nations in cybersecurity index.

Table 1. Top 10 Member States with the highest commitment to cybersecurity [10]

\begin{tabular}{|l|l|l|l|l|l|l|}
\hline Country & $\begin{array}{l}\text { GCI } \\
\text { Score }\end{array}$ & Legal & Technical & Organizational & $\begin{array}{l}\text { Capacity } \\
\text { Building }\end{array}$ & Cooperation \\
\hline Singapore & 0.92 & 0.95 & 0.96 & 0.88 & 0.97 & 0.87 \\
\hline USA & 0.91 & 1 & 0.96 & 0.92 & 1 & 0.73 \\
\hline Malaysia & 0.89 & 0.87 & 0.96 & 0.77 & 1 & 0.87 \\
\hline Oman & 0.87 & 0.98 & 0.82 & 0.85 & 0.95 & 0.75 \\
\hline Estonia & 0.84 & 0.99 & 0.82 & 0.85 & 0.94 & 0.64 \\
\hline Mauritius & 0.82 & 0.85 & 0.96 & 0.74 & 0.91 & 0.70 \\
\hline Australia & 0.82 & 0.94 & 0.96 & 0.86 & 0.94 & 0.44 \\
\hline Georgia & 0.81 & 0.91 & 0.77 & 0.82 & 0.90 & 0.70 \\
\hline France & 0.81 & 0.94 & 0.96 & 0.60 & 1 & 0.61 \\
\hline Canada & 0.81 & 0.94 & 0.93 & 0.71 & 0.82 & 0.70 \\
\hline
\end{tabular}

\section{MERITS AND DEMERITS OF E-GOVERNANCE}

\section{A. Merits of e-governance}

1. Increased portfolio of services to citizens

2. Efficiency and cost effectiveness

3. Government transparency keeps citizens informed about the work and policies to be implemented in future resulting in accountability of government

4. Tasks become easier to perform in an electronic way, e.g. Phone number or address change in database

5. Easier way for the public to be involved in political views, voter awareness can be achieved.

6. It is convenient and cost effective for business.

7. Current information at your fingertips.

8. E-democracy can be developed. Blogging and interactive surveys can allow government to have a look at the views, complaints and expectations of public in real time.

9. Less paper use produces significant paper savings.
10. Since citizens are getting information and forms online, they hardly need to visit office which subsequently results into less fuel use and indirectly less air pollution.

11. Speed, efficiency and convenience

12. Improved record keeping and back-up

\section{B. Demerits of e-governance}

1. Lack of computer and internet access in India to provide digital platform to rural areas people

2. Reliability of information on site, security is major concern

3. Social barriers: People pull others back when it comes to using e-services, they still hesitate

4. Economic barriers: It needs computer infrastructure and computer education which still is very costly in India

5. Political unwillingness: Transparency leads to political unwillingness to hide scams and corruptions 


\section{Available online at www.ijrat.org}

6. Public unwillingness: Public hardly take interest in learning new ways of e-governance

7. Trust: Trust is the main area of concern when it comes to implementation, because public is more used to routine paper work

8. Development: E-Governance is in its early stages of development. Using new technologies may lead to miscommunication.

9. Cyber/Internet Illiteracy: Many of the old employees are illiterate in terms of computer and internet. They will need a lot of training and this process will cost a lot.

10. Hyper Surveillance: Increased data exchanges goes both ways i.e. Government to Citizen (G2C) and vice-versa. Once there is vast increase in case of e-Governance services, lots of public data will be easily available to government, it may result into data leakage or misuse of public information for private profits.

11. When government has easy access to countless information, it will lead to loss of public privacy.

\section{CONCLUSION}

The performance of e-governance is expected to improve with the application of relevant lessons from strategic management during planning and implementation phases. E-Governance is an important tool in fighting the current pandemic. If India take this opportunity to improve e-governance infrastructure and resources, then India would definitely get its growth back, and more structural reforms that will change the "course of country" and in such pandemic situation India can save many lives - both now and in the future.

\section{REFERENCES}

[1] India.gov.in. (2015). National e-Governance Plan. Available at https://india.gov.in/e-governance/initiatives/central-initiatives.

[2]Kumar, S. (2016). e-Governance in India. Imperial Journal of Interdisciplinary Research (IJIR), 2(2), 2454-1362.

[3] Mitra, K. (2012). Rise of e-Governance. Indian Institute of Foreign Trade. Working Paper.

[4] Department of Information Technology, Ministry of Communication and Information technology, Government of India (2010) Background papers national e-governance plan, meeting of the national e-governance advisory group, New Delhi, 12 Nov 2010.

[5]Kettl DF (2002) The transformation of governance. John Hopkins University Press, USA

[6]Dev B (1999) E-governance: India in the 21st century. Cyber India Online Ltd. http://www.ciol.com/content/services/egov/

[7] https://www.orfonline.org/expert-speak/egovernance-possibilities-indiapost-covid19-era-66316/

[8] https://www.un.org/development/desa/dpad/publication/un-desa-policybrief-61-covid-19-embracing-digital-government-during-the-pandemi c-and-beyond/

[9] https://government.economictimes.indiatimes.com/news/digital-india/he ad-govt-launches-digital-platform-covid-india-seva-for-real-time-grie vance-redressal/75284732

[10] https://publicadministration.un.org/Portals/1/Images/E-Government\% 20Survey\%202018_FINAL\%20for\%20web.pdf 